\title{
KOMPETENSI PENGAWAS MADRASAH DI KOTA KENDARI
}

\section{Madrasah Supervisor Competency in Kendari}

\author{
Badruzzaman \\ Balai Penelitian dan Pengembangan Agama Makassar \\ Jl. A.P.Pettarani No. 72 Makassar \\ Email: bz69badruzzaman@rocketmail.com
}

Naskah diterima tanggal 30 Mei 2014. Naskah direvisi tanggal 27 Juni 2014. Naskah disetujui tanggal 3 Juli 2014

\begin{abstract}
Abstrak
Posisi pengawas dalam sistem pendidikan nasional Indonesia sangat strategis.Tugas dan fungsi sebagai tenaga supervisor akademik dan manajerial serta evaluator terhadap peningkatan kualitas kepala madrasah dan guru mata pelajaran menuntutnya untuk berkerja secara professional.Namun beberapa hasil riset parsial menyatakan bahwa tingkat profesionalitas pengawas masih tergolong rendah.Riset kali ini menelusuri tingkat kompetensi pengawas secara komprehensif, yaitu mencakup kompetensi akademik, manajerial, evaluasi pendidikan kelitbangan, kepribadian, dan sosial.Penelitian survei di Kota Kendari pada tahun 2012 mengumpulkan data dengan metode kuantitatif dan analisis deskriptif kuantitatif, terhadap 25 responden (pengawas).Penelitian bertujuan untuk menemukan tingkat kompetensi pengawas dengan harapan dapat bermanfaat terhadap kebijakan peningkatan kualitas pengawas madrasah.Ditemukan, bahwa secara umum tingkat kompetensi pengawas madrasah di Kota Kendari terkategori 'sedang'. Dan tingkat kompetensi pengawas berdasarkan karanteristik pengawas tampak variatif.Peningkatan kompetensi pengawas perlu diintensifkan terutama peningkatan pengetahuan, sikap, dan keterampilan yang berkaitan dengan pembinaan dan bimbingan terhadap kepala madrasah dan guru mata pelajaran, penelitian, penilaian kinerja, dan kemahiran membangun kemiteraan.
\end{abstract}

Kata kunci :madrasah, pengawas, kompetensi, Kendari

\begin{abstract}
Supervisor position in Indonesian national education system is very strategic. Their duty to be an academic supervisor and evaluator to headmasters and teacher of madrasah is a subject to professional work. However, some researches have shown that supervisors professionalism level in Indonesia is still relatively low. The research tried to observe comprehensively on their academic, managerial, knowledge on research and development, personality, and social competencies. Research was done to collect data from 25 supervisors in Kendari in 2012 with quantitative method, then analyzed descriptively and quantitatively. The research aims to find the level of supervisor competency in Kendari that hopefully can be beneficial for policies to improve their level of professionalism. Research showed that their level of competencies is average. Government needs to intensify activities to enhance their knowledge and skill in supervising, mentoring and coaching headmaster, teachers, researching, and building partnership.
\end{abstract}

Keywords: madrasah, supervisor, competency, Kendari

\section{PENDAHULUAN}

$\mathrm{K}$ etentuan perundang-undangan menunjukkan bahwa pengawas satuan pendidikan pada jalur sekolah adalah tenaga kependidikan profesional berstatus pegawai negeri sipil yang diangkat dan diberi tugas dan wewenang secara penuh oleh pejabat berwenang untuk melakukan pembinaan dan pengawasan pendidikan baik pengawasan akademik maupun pengawasan manajerial pada satuan pendidikan yang ditunjuk. Peraturan Menteri Pendidikan Nasional RI Nomor 12 Tahun 2007 tentang Standar Pengawas Sekolah/ Madrasah menegaskan bahwa seorang pengawas harus memiliki 6 (enam) kompetensi minimal, yaitu kompetensi keperibadian, supervisi manajerial, 
supervisi akadimik, evaluasi pendidikan, penelitian dan pengembangan, serta kompetensi sosial (Lamp. Permen Diknas 12 Thn 2007: 4-17). Pengawasan manajerial sasarannya adalah kepala sekolah dan staf sekolah lainnya, sedangkan sasaran supervisi akademik sasarannya adalah guru (Dirjen PMPTK Dep.Diknas, 2009: 14).

Selain itu, jika dilihat dari realitas kondisi sekolah dan sumber daya manusia yang dimiliki oleh mayoritas madrasah di Indonesia saat ini masih sangat menghajatkan kehadiran dan keterlibatan pengawas sekolah.Diakui atau tidak, kualitas madrasah baik dari sisi akademik maupun manajerial, mayoritas masih sangat rendah.Dalam konteks ini peran pengawas sekolah sangat strategis dan menentukan.Untuk itu para pengawas madrasah ditantang untuk benar-benar memiliki dan bekerja sesuai dengan tuntutan profesionalismenya.

Penelitian tentang kompetensi pengawas pendidikan telah banyak dilakukan baik berupa upaya peningkatan kualitasnya pengawas maupun kondisi kualitasnya. Penelitian kualitatif yang dilakukan oleh Marwan Seleuw di Jayapura tahun 2009 tentang pelaksanaan supervisi yang dilakukan oleh pengawas ditempuh melalui empat komponen yakni (1) proses/langkah supervisi meliputi; persiapan, pelaksanaan kegiatan supervisi dan tindak lanjut dan instrumen penilaian, (2) gaya supervisi yang digunakan yakni gaya demokrasi (3) teknik/metode supervisi yang digunakan meliputi; teknik kunjungan lansung dan teknik tidak kunjungan langsung, dan (4) problem supervisi yang di hadapi meliputi problem dari guru, anak, kepala madrasah, pengawas, dan dari Departemen Agama (Seleuw 2009, lib.uin-malang.ac.id.).

Suhri Nasution melakukan penelitian tentang kompetensi supervisi akademik Pengawas PAI di wilayah Kementerian Agama Provinsi Banten. Penelitian deskriptif kuantitatif dilakukan terhadap sejumlah 65 orang peserta Diklat Peningkatan Kompetensi Pengawas Sekolah Dan Pengawas Madrasah Angkataan Ke II tahun 2010 yang dilaksanakan di Badan Diklat Provinsi Banten. Hasil penelitian menyimpulkan bahwa, tingkat kompetensi akademik pengawas PAI di lingkungan Kemengan Provinsi Banten cukup baik, yaitu angka 66,7. Pengawas memiliki kompetensi tertinggi pada aspek Memahami konsep, prinsip, teori/teknologi, karakteristik dan kecendrungan perkembangan proses pembelajaran/bimbingan tiap mata pelajaran dalam mata pejalaran yang relevan disekolah dan Membimbing guru dalam memilih dan menggunakan strategi/metode/ teknik pembelajaran/bimbingan yang dapat mengembangakan berbagai potensi siswa melalui mata-mata pelajaran dalam rumpun mata pelajaran PAI, yaitu mencapai angkat 100, Sementara guru memiliki kompetensi terendah pada 'Memahami konsep, prinsip, teori dasar, karakteristik dan kecendrungan perkembangan tiap mata pelajaran dalam rumpun mata pelajaran PAI dan Membimbing guru dalam melaksanakan kegiatan pembelajaran/bimbingan (di kelas, laboratorium dan atau dilapangan) untuk tiap mata pelajaran dalam rumpun mata pelajaran PA, yaitu hanya mencapai angka 40 (Nasution, 2010, bdkjakarta. kemenag.go.id).

Balai Penelitian dan Pengembangan Kemeterian Agama Makassar telah melakukan penelitian tentang Performansi Pengawas Guru Agama Islam di beberpa Kabupaten di Sulawesi Tenggara pada tahun 2004 menemukan bahwa performansi Pengawas PAI tingkat Dasar dan Menengah tampak lebih rendah daripada performansi Guru PAI (Balai Litbang Agama Makassar, 2004). Oleh karena itu penelitian tentang kompetensi pengawas dipandang tetap urgen untuk dilakukan, pada lima aspek kompetensi berdasarkan Peraturan Menteri Pendidikan Nasional RI Nomor 12 Tahun 2007 tentang Standar Pengawas Sekolah/ Madrasah.

Berdasarkan uraian terdahulu, maka permasalahan penelitian ini adalah: Bagaimana Tingkat Kompetensi Pegawas pendidikan di Madrasah dan PAI di Sekolah? Pertanyaan ini dikaitkan dengan tingkat kompetensi pengawas pendidikan madrasah dan PAI, tingkat kompetensi pengawas berdasarkan usia saat diangkat, jabatan sebelumnya, dan kesesuaian disiplin ilmu dengan bidang studi yang diawasi.

\section{Tinjauan Pustaka}

Peraturan Menteri Pendidikan Nasional RI Nomor 12 Tahun 2007 tentang Standar Pengawas Sekolah/Madrasah menegaskan bahwa seorang pengawas harus memiliki 6 (enam) kompetensi minimal, yaitu kompetensi keperibadian, supervisi manajerial, supervisi akadimik, evaluasi pendidikan, penelitian dan pengembangan, kompetensi keperibadian serta kompetensi sosial (Lamp. Permen Diknas 12 Tahun, 2007: 4-17).

Supevisi manajerial adalah supervisi yang berkenaan dengan aspek pengelolaan sekolah yang terkait langsung dengan peningkatan efisiensi dan efektivitas sekolah yang mencakup perencanaan, koordinasi, pelaksanaan, penilaian, pengembangan kompetensi sumberdaya manusia (SDM) kependidikan dan sumberdaya lainnya 
(Direktorat Tenaga Kependidikan Kemendiknas, 2009:20). Berdasarkan Lampiran Permen Diknas Nomor 12 Tahun 2007, kompetensi keperibadian pengawas terdari atas: (1) Memiliki tanggungjawab sebagai pengawas satuan pendidikan; (2) Kreatif dalam bekerja dan memecahkan masalah baik yang berkaitan dengan kehidupan pribadinya maupun tugas-tugas jabatannya; (3) Memiliki rasa ingin tahu akan hal-hal baru tentang pendidikan dan ilmu pengetahuan, teknologi dan seni yang menunjang tugas pokok dan tanggungjawabnya; (4) Menumbuhkan motivasi kerja pada dirinya dan pada takeholder pendidikan(Lamp. Permen Diknas 12 Thn 2007: 2-3).

Kompetensi supervisi akademik adalah adalah kemampuan pengawas sekolah dalam melaksanakan pengawasan akademik yakni menilai dan membina guru dalam rangka mempertinggi kualitas proses pembelajaran yang dilaksanakannya, agar berdampak terhadap kualitas hasil belajar siswa (Dirjen PMPTK Dep. Diknas, 2009: 15).

Kompetensi Supervisi Akademik Pengawas meliputi: pertama memahami konsep, prinsip, teori dasar,karakteristik, dan kecenderungan perkembangan tiap mata pelajaran dalam rumpun mata pelajaran yang relevan di sekolah menengah yang sejenis; kedua memahami konsep, prinsip, teori/teknologi,karakteristik, dan kecenderungan perkembangan proses pembelajaran/bimbingan tiap mata pelajaran dalam rumpun mata pelajaran yang relevan di sekolah menengah yang sejenis; ketiga membimbing guru dalam menyusun silabus tiap mata pelajaran dalam rumpun mata pelajaran yang relevan di sekolah menengah yang sejenis berlandaskan standar isi, standar kompetensi dan kompetensi dasar, dan prinsip-prinsip pengembangan KTSP; keempat membimbing guru dalam memilih dan menggunakan strategi/metode/ teknik pembelajaran/bimbingan yang dapat mengembangkan berbagai potensi siswa melalui mata-mata pelajaran dalam rumpun mata pelajaran yang relevan di sekolah menengah yang sejenis.

Kelima membimbing guru dalam menyusun rencana pelaksanaan pembelajaran (RPP) untuk tiap mata pelajaran dalam rumpun mata pelajaran yang relevan di sekolah menengah yang sejenis; keenam membimbing guru dalam melaksanakan kegiatan pembelajaran/bimbingan (di kelas, laboratorium, dan atau di lapangan) untuk tiap mata pelajaran dalam rumpun mata pelajaran yang relevan di sekolah menengah yang sejenis; ketujuh membimbing guru dalam mengelola, merawat, mengembangkan dan menggunakan media pendidikan dan fasilitas pembelajaran/bimbingan tiap mata pelajaran dalam rumpun mata pelajaran yang relevan di sekolah menengah yang sejenis kedelapan memotivasi guru untuk memanfaatkan teknologi informasi dalam pembelajaran/ bimbingan tiap mata pelajaran dalam rumpun mata pelajaan yang relevan di sekolah menengah yang sejenis (Lamp. Permen Diknas 12 Thn 2007: 4-5).

Kompetensi evaluasi pendidikan adalah kemampuan yang dimiliki oleh pengawas melakukan bimbingan kepada guru dan kepala sekolah/madrasah menyusun kriteriadan indikator keberhasilan pembelajaran agar dapat menjalankan tugas masing-masing (Dirjen PMPTK Dep. Diknas, 2009:1).Kompetensi evaluasi pendidikan pengawas mencakup: menyusun kriteria dan indikator keberhasilan pendidikan dalam bidang pengembangan dan pembelajaran/bimbingan di sekolah/madrasah; membimbing guru dalam menentukan aspek-aspek yang penting dinilai dalam pembelajaran/bimbingan tiap bidang pengembangan mata pelajaran di sekolah/ madrasah; menilai kinerja kepala sekolah, guru, dan staf sekolah dalam melaksanakan tugas pokok dan tanggung jawabnya untuk meningkatkan mutu pendidikan dan pembelajaran/bimbingan tiap bidang pengembangan mata pelajaran di sekolah; memantau pelaksanaan pembelajaran/bimbingan dan hasil belajar siswa serta menganalisisnya untuk perbaikan mutu pembelajaran/bimbingan tiap bidang pengembangan mata pelajaran di sekolah/ madrasah; membina guru dalam memanfaatkan hasil penilaian untuk perbaikan mutu pendidikan dan pembelajaran/bimbingan tiap bidang pengembangan mata pelajaran di sekolah/ madrasah; mengolah dan menganalisis data hasil penilaian kinerja kepala seko-lah/madrasah, kinerja guru, dan staf sekolah/madrasah(Lamp. Permen Diknas 12 Tahun 2007: 4-5).

Kompetensi penelitian dan pengembangan adalah kegiatan pengembangan profesi pengawas dalam rangka pengamalan ilmu dan pengetahuan, teknologi dan ketrampilan untuk peningkatan mutu baik bagi proses belajar mengajar dan profesionalisme tenaga kependidikan lainnya maupun dalam rangka menghasilkan sesuatu yang bermanfaat bagi pendidikan dan kebudayaan (Dirjen PMPTK Dep. Diknas, 2009:14).Kompetensi Penelitian dan Pengembangan pengawas mencakup: menguasai berbagai pendekatan, jenis, dan metode penelitian dalam pendidikan; menentukan masalah kepengawasan yang penting diteliti baik untuk keperluan tugas pengawasan maupun untuk pengembangan karirnya sebagai pengawas; menyusun proposal penelitian 
pendidikan baik proposal penelitian kualitatif maupun penelitian kuantitatif; melaksanakan penelitian pendidikan untuk pemecahan masalah pendidikan, dan perumusan kebijakan pendidikan yang bermanfaat bagi tugas pokok tanggung jawabnya; mengolah dan menganalisis data hasil penelitian pendidikan baik data kualitatif maupun data kuantitatif; menulis karya tulis ilmiah (PTS) dalam bidang pendidikan dan atau bidang kepengawasan dan memanfaatkannya untuk perbaikan mutu pendidikan; menyusun pedoman/ panduan dan/atau buku/modul yang diperlukan untuk melaksanakan tugas pengawasan di sekolah/ madrasah; memberikan bimbingan kepada guru tentang penelitian tindakan kelas, baik perencanaan maupun pelaksanaannya di sekolah/madrasah (Lamp. Permen Diknas 12 Tahun 2007:6-7).

Kompetensi kepribadian pengawas adalah kemampuan pengawas berkaitan dengan aspek nilai dan sikap serta motivasi dan komitmen.Kompetensi ini terdiri dari dua materi, yaitu yaitu: pengenalan diri, mengembangkan diri, dan memberdayakan diri serta kreativitas dan pengambilan keputusan (Dirjen PMPTK Dep. Diknas, 2009:1). Kompetensi keperibadian pengawas mencakup: memiliki tanggungjawab sebagai pengawas satuan pendidikan; kreatif dalam bekerja dan memecahkan masalah baik yang berkaitan, kehidupan pribadinya maupun tugas-tugas jabatannya; memiliki rasa ingin tahu akan hal-hal yang baru tentang pendidikan dan ilmu pengetahuan, teknologi dan seni yang menunjang tugas pokok dan tanggung jawabnya; menumbuhkan motivasi kerja pada dirinya dan pada stakeholder (Lamp. Permen Diknas 12 Tahun 2007:7).

Kompetensi Sosial pengawas adalah kemampuan pengawas berkaitan dengan aspek nilai dan sikap serta motivasi dan komitmen. Kompetensil ini terdiri dari dua materi, yaitu: mengembangkan kemitraan dan tim kerja, serta gaya kerja dan penyelesaian konflik(Dirjen PMPTK Dep. Diknas, 2009:1).Kompetensi Sosial pengawas mencakup: bekerjasama dengan berbagai pihak dalam rangka meningkatkan kualitas diri untuk dapat melaksanakan tugas dan tanggung jawabnya; aktif dalam kegiatan asosiasi pengawas satuan pendidikan(Lamp. Permen Diknas 12 Tahun 2007:6).

\section{METODE PENELITIAN}

Penelitian Applied (Mulyatningsih, 2013: 4) dilakukan pada tahun 2012 di Kota Kendari dengan menggunakan pendekatan survei (Arikunto, 2005: 236-237) di lapangan/Field Research (Raco, 2010:
9) menyasar variabel secara ekspos-fakto (Gulo, 2010: 20) . Unit analisis adalah seluruh pengawas madrasah di Kota Kendari, sejumlah 25 orang. Data dikumpulkan dengan angket dan pedoman wawancara dari pengawas dan instansi terkait. Data kuantitatif dianalisis secara deskriptif kuantitatif dengan dengan menggunakan Program SPSS (Mustari, 2012: 40-46) sehingga mendapatkan kategori: $0.0-1.0=$ sangat rendah; $1.1-2.0=$ rendah; 2.1-3.0 = sedang, 3.1-4.0 = tinggi; dan 4.1-5.0 = sangat tinggi. Sedangkan data kualitatif dianalisis dengan cara klasifikasi, reduksi, sintesis, dan interpertasi. Penyajian data dilakukan dengan cara naratif interpertatif dengan menggunakan tabel.

\section{PEMBAHASAN}

Jumlah pengawas madrasah di Kota Kendari sebanyak 25 orang.Karanteristik pengawas tersebut, dapat pula diamati pada pembahasan berikutnya, yaitu identitas responden.Sampel responden penelitian ini mengambil semua pengawas madrasah yang ditugaskan di Kota Kendari.

Saat ini, Kelompok Jabatan Pengawas (POKJAWAS) di Lingkungan Kementerian Agama Kota Kendari dipimpin oleh Drs. H. Alimuddin K. dan dibantu beberapa orang pengawas yang menjadi pengurus organisasi provinsi ini. Pokjawas Madrasah Kota Kendari melaksanakan tugas dan fungsinya kepengawasan pendidikan di madrasah telah menyusun beberapa agenda rutin kepengawasan, yaitu: mengumpulkan data sekolah, guru, dan siswa; membuat program kerja pengawasaan; menyiapkan blangko-blangko pengawasan; melakukan kunjungan ke sekolah; melakukankunjungan kelas; mengadakan konsultasi perorangan; mengadakan konsultasi kelompok KKG dan MGMP mengadakan kegiatan evaluasi guru PAI; memantau perkembangan kurukulum; memantau pelaksanaan evaluasi pembelajaran; memantau penyelenggaraan pembinaan; mengadakan konsultasi sesama pengawas; mengadakan hubungan kerja sama; menghadiri kegiatan pembinaan; melaksanakan tugas-tugas lain yang diminta oleh atasan; melakukan kegiatan lintas sektoral; menyiapkan laporan (Sumber data: Papan Program Kerja Pokjawas Madrasah Kota Kendari).

Kegiatan-kegiatan rutin diatas dilakukan sebagai tugas dan fungsi pokok Pokjawas sebagai pengawas pendidikan. Karenanya konsekwesi penganggaran dana untuk mendukung pelaksanaan kegiatan tersebut tidak disiapkan oleh Kementerian Agama kota maupun provinsi. Pendanaan kegiatan tersebut telah diinterpertasi secara kebijakan 
berupa inklud pada tunjangan pengawas, antara lain: tunjangan jabatan pengawas, tunjangan transportasi, dan tunjangan sertifikasi.

Karenanya, kegiatan-kegiatan kepengawasan cenderung dilaksanakan secara personal oleh masing-masing pengawas madrasah.Pelaksanaan kepengawasan dilaksanakan atas motivasi dan inisiatif personal untuk menunaikan tugas dan fungsinya dan juga dalam rangka meningkatkan kompetensi serta bukti administratif kenaikan jabatan fungsional.Kegiatan-kegiatan personal yang dimaksud berkaitan dengan berkaitan dengan tugas kegiatan rutin kepengawasan.

Meskipun demikian, kegiatan-kegiatan kependidikan yang bertaraf nasional, seperti Ujian Semester, Ujian Kenaikan Kelas, Ujian Akhir Sekolah, Ujian Akhir Nasional, diprogramkan secara nasional dan pengawas madrasah turut terlibat aktif dalam kegiatan tersebut.

Pola kegiatan Pokjawas, tersebut didasarkan pada Juklat Pembentukan Poksjawas yang salah satu item dijelaskan bahwa sumber dana Pokjawas dalam menjalankan kegiatan kepangawasan diperoleh dari bantuan pemerintah, iuran anggota pengawas, dan sumbangan dari pihak lain.

\section{Indentitas Responden}

Jumlah responden yang dijadikan sampel dalam penelitian ini adalah 25 pengawas madrasah terdiri atas 14 laki-laki dan 11 perempuan. Berdasarkan tingkat pendidikan, tampak bahwa dominan respoden berpendidikan terakhir S1, yaitu sejumla 64\%.Sementara pengawas yang berpendidikan terakhir S2 terindentifikasi sejumlah 9 orang.

Usia responden pun tampak bervariasi. Namun dominan responden telah berusia diatas 50 tahun,sejumlah $70 \%$ responden.Sejumlah 36\% responden teridentifikasi telah berusia antara 52-56 tahun dan yang berusia 57-61 tahun teridentifikasi sejumlah $40 \%$ dari seluruh responden.Berdasarkan lama bertugas, tampak bahwa dominan responden telah bertugas sebagai pengawas madrasah salama $1-10$, yaitu sejumlah $96 \%$ responden. Teridentifikasi bahwa terdapat sejumlah 15 orang responden yang telah menjabat pengawas madrasah salama 1-5 tahun, 9 orang yang telah bertugas selama 5-10 tahun. Dominan responden terangkat menjadi pengawas pada pangkat Penata Tk.I, III/d (28\% responden) dan Pembina, IV/a (56\% responden). Namun terdapat pula responden yang terangkat menjadi pengawas pada saat berpangkat Penata Muda Tk.I

Diamati berdasarkan usia saat diangkat menjadi pengawas, tampak bahwa dominan responden diangkat pada usia di atas 45 tahun, sejumlah lebih $70 \%$ responden. Namun dari 5 kategori pengelompokan usia yang telah ditentukan, dominan responden diangkat menjadi pengawas pada usia 47-51 tahun yaitu $44 \%$ responden, dan usia 51-55 tahun sebanyan $12 \%$ responden. Diamati berdasarkanjenis jabatan sebelumnya tampak bahwa dominan responden terangkat menjadi pengawas disaat menjadi kepala madrasah (32\% responden) dan guru mata pelajaran (36\% responden).Namun terdapat pula seorang responden yang menyatakan bahwa jabatan sebelumnya adalah staf pada bidang tertentu.Berdasarkan kesesuaian disiplin ilmu yang dimiliki dengan mata pelajaran yang diawasi pun tampak variatif.Dominan responden memiliki disiplin ilmu yangsesuai dengan mata pelajaran yang dimiliki.Namun beberapa responden menyatakan, bahwa disiplin ilmu yang dimiliki kurang sesuai dengan mata pelajaran yang diawasi, yaitu sejumlah $12 \%$ orang yang berdisiplin ilmu agama.Lebih jelasnya dapat diamati tabel 1 .

Tabel 1 Jumlah Responden Berdasarkan Usia Saat Diangkat Menjadi Pengawas, Jabatan Sebelumnya, dan Kesesuaian Disiplin Ilmu dengan Mata Palajaran Yang Diawasi

\begin{tabular}{ccccccccc}
\hline Usia & Jumlah & Persen & $\begin{array}{c}\text { Jabatan } \\
\text { Sebelumnya }\end{array}$ & Jumlah & Persen & $\begin{array}{c}\text { Keseuaian Mapel } \\
\text { Diawasi }\end{array}$ & Jumlah & Persen \\
\hline 32-36 Th & 1 & 4 & Pej. Non Pend. & 6 & 24 & Umum Tdk Sesuai & 0 & 0 \\
37-41 Th & 3 & 12 & Pej. Pend. & 2 & 8 & Agama Tdk Sesuai & 3 & 12 \\
42-46 Th & 7 & 28 & Kamad & 8 & 32 & Umum Sesuai & 2 & 8 \\
47-51 Th & 11 & 44 & Guru MP & 9 & 35 & Agama Sesuai & 20 & 80 \\
52-56 Th & 3 & 12 & & & & & & \\
\hline
\end{tabular}


Tingkat Kompetensi Pengawas Madrasah Implementasi Responden Terhadap Indikator Kompetensi

Pengawas madrasah dituntut memiliki kompetensidalam melaksanakan tugas pokok dan fungsinya.Peraturan Menteri Diknas RI Nomor 12 Tahun 2007, tentang Standar Pengawas mencantumkan enam macam kompetensi yang harus dimiliki pengawas pendidikan adalah kompetensi keperibadian, supervisi manajemen, supervisi akademik, evaluasi pendidikan, penelitian dan pengembangan, dan sosial. Lampiran Peraturan Menteri Diknas RI Nomor 12 Tahun 2007, tentang Standar Pengawas, dinyatakan bahwa setiap kompetensi itu memiliki indikator. Indikator- indikator tersebutlah yang dijadikan alat ukur untuk menentukan tingkat kompetensi pengawas madrasah (sesuai penjelasan terdahulu).

Setelah dilakukan analisis deskriptif terhadap hasil isian angket pengawas, maka diperoleh gambaran bahwa tingkat kompetensi respondentampak variatif.Tampak pula persebaran tingkat kompetensi responden dominan menjauhi rerata tingkat kompetensi. Hal ini mengindikasikan bahwa tingkat kompetensi pengawas/responden bervariasi (range skor 115 dan standar deviasi: 21.45). Nilai Kompetensi rata-rata responden mencapai 56, meskipun terdapat responden yang nilai kompetensinya hanya mencapai 41 , namun nilai kompetensi tertinggi mencapai 77 .

Tabel 2 Deskripsi Statistik Tingkat Kompetensi Pengawas

\begin{tabular}{cccccccc}
\hline Tingkat & Range & Min & Maks & Rerata & Ideal & Std Dev & N \\
\hline Skor & 115 & 134 & 249 & 183.56 & 325 & 21.45 & 25 \\
Nilai & 35 & 42 & 76 & 56.48 & 100 & & \\
\hline
\end{tabular}

Tingkat kompetensi tersebut dapat dibuktikan dari hasil analisis implementasi responden terhadap masing-msing indikator kompetensi.Pada kompetensi keperibadian, satu indikator yang telah diimplementasikan oleh sejumlah 100\% responden yaitu indikator selalu menumbuhkan motivasi kerja.Dua indikator telah diimplementasikan dengan tepat oleh sejumlah lebih $96 \%$ responden, yaitu kreatifitas kerja dan memecahkan masalah kepengawasan, dan rasa ingin tahu yang tingg. Dan indikator komitmen kerja dan tanggung jawab telah diimplementasikan dengan tepat oleh sejumlah $72.00 \%$ responden.

Tabel 3 Implementasi Responden Terhadap Indikator Kompetensi Keperibadian

\begin{tabular}{clc}
\hline No. & Indkator Kompetensi Keperibadian & Implementasi \\
\hline 1 & Komitmen dan tanggung jawab & $72.00 \%$ \\
2 & Kreatifitas kerja dan memecahkan & $96.00 \%$ \\
& masalah & $96.00 \%$ \\
3 & Rasa ingin tahu yang tinggi & $100.00 \%$ \\
4 & Menumbuhkan motivasi kerja & \\
\hline
\end{tabular}

Jumlah responden yang mengimplementasikan indikator-indikator Kompetensi Supervisi Manajerial berada pada sejumlah 88\%-100\% responden. Indikator yang telah diimplementasikan secara tepat oleh seluruh responden (100\%) adalah; (1) Penerapan metode supervise untuk mengetahui perkembangan pelaksanan rencana/ program madrasah; (2) penerapan prinsip-prinsip kepengawasan yang demokratis dan obyektif, bersifat terbuka, supervisi berkesinambungan, konfehensif dan integral; (3) Penerapan pengawasan berdasarkan visi, misi, tujuan dan program pendidikan; (4) Penerapan penyusunan metode kerja dan instrument untuk melaksanakan tugas pokok dan fungsi; dan (5) Membatu kepala madrasah menemukan kelebihan dan kekurangan pelaksanaan tugas pokok.

Indikator yang telah diimplementasikan secara tepat oleh sejumlah $90-99 \%$ responden adalah: (1) Berdiskusi dengan kepala madrasah untuk mengetahui kekuatan dan kelamahan madrasah; (2) Tidak bersifat otoriter dalam kelakukan kepengawasan; (3) Membina kepala madrasah menyusun visi, misi tujuan madrasah, dan menyusun program pengawasan dan melakukan kegiatan konseling; (4) Membantu kepala madrasah mempersiaplan akreditasi madrasah.

Sementara, indikator yang telah diimplementasikan secara tepat oleh sejumlah $88 \%$ responden adalah membantu kepala madrasah mempersiaplan akreditasi madrasah. 
Tabel 4 Implementas Responden TerhadapIndikator Kompentensi Supervisi Manajerial

\begin{tabular}{|c|c|c|}
\hline No & Indkator Kompetensi Sup Manajerial & Implementasi \\
\hline \multirow[t]{4}{*}{1} & Metode Supervisi & \\
\hline & $\begin{array}{l}\text { 1.1 Kegiatan untuk mengetahui } \\
\text { perkembangan pelaksanaan } \\
\text { rencana/program mad. }\end{array}$ & $100.00 \%$ \\
\hline & $\begin{array}{l}\text { 1.2 Kegiatan untuk mengtahui } \\
\text { kesuksesan pelaksanaan program } \\
\text { madrasah }\end{array}$ & $100.00 \%$ \\
\hline & $\begin{array}{l}\text { 1.3 Berdiskusi dgn Kamad untuk } \\
\text { mengetahui kekuatan dan } \\
\text { kelamahan madrasah }\end{array}$ & $96.00 \%$ \\
\hline \multirow[t]{6}{*}{2} & Prinsip Kepengawasan & \\
\hline & 2.1 Tidak otoriter & $92.00 \%$ \\
\hline & 2.2 Bersifat terbuka & $100 \%$ \\
\hline & 2.3 Supervisi berkesinambung & $100.00 \%$ \\
\hline & 2.4 Demokratis dan obyektif & $100 \%$ \\
\hline & 2.5 Komftehensif dan integral & $100 \%$ \\
\hline 3 & $\begin{array}{l}\text { Pengawasan berdasarkan visi, misi, } \\
\text { tujuan dan program pendidikan }\end{array}$ & $100.00 \%$ \\
\hline 4 & $\begin{array}{l}\text { Memyusun metode kerja dan } \\
\text { instrumen utk melaksanakan tupoksi }\end{array}$ & $100.00 \%$ \\
\hline \multirow[t]{4}{*}{5} & $\begin{array}{l}\text { Membina Kamad dalam pengelolaan dan } \\
\text { administrasi madrasah. }\end{array}$ & \\
\hline & $\begin{array}{l}\text { 5.1 Merumuskan visi, misi, dan } \\
\text { tujuan madrasah }\end{array}$ & $92.00 \%$ \\
\hline & $\begin{array}{l}\text { 5.2 Membuat pedoman tertulis } \\
\text { mengenai ketatausahaan }\end{array}$ & $88.00 \%$ \\
\hline & 5.3 Menyusun program pengawasan & $96.00 \%$ \\
\hline 6 & $\begin{array}{l}\text { Membantu Kamad dalam } \\
\text { melakasanaka bimbingan konseling }\end{array}$ & $96.00 \%$ \\
\hline 7 & $\begin{array}{l}\text { Membantu Kamad menemukan } \\
\text { kelebihan dan kekurangan } \\
\text { pelaksanaan tugas pokok }\end{array}$ & $100.00 \%$ \\
\hline 8 & $\begin{array}{l}\text { Membantu Kamad mempersiapkan } \\
\text { akreditasi madrasah. }\end{array}$ & $92.00 \%$ \\
\hline
\end{tabular}

Sejumlah 10 item yang dijadikan indikator untuk mengukur tingkat kompetensi supervisi akademik pengawas, tak satupun indikator yang telah diimplementasikan oleh seluruh responden, namun indikator-indikator tersebut hanya diimplementasikan oleh sejumlah 92\%-100\% responden. Indikator yang telah diimplementasikan oleh sejumlah diatas $100 \%$ adalah: (a) memahami perkembangan mata palajaran dan (b) proses pembelajaran mata pelajaran yang ditugaskan; (c) membimbing guru menyusun menyusu RPP, d) melaksanakan kegiatan pembelajaran, dan(e) menggunakan media dan fasilitas pembelajaran; dan (f) memotivasi guru memanfaatkan teknologi informasi dalam pembeljaran.
Indikator yang diimplementasikan sejumlah 92\%-99\% responden adalah (a) membimbing guru menyusun silabus berdasarkan Standar Isi, Standar Kompetensi, Kompetensi Dasar dengan prinsip pengembangan KTSP (b) memilih dan menggunakan strategi/metode/teknik pembelajaran, (c) mengelola dan mengembangkan media dan fasilitas pembelajaran, dan (d) merawat media dan fasilitas pembelajaran.

Tabel 5 Implementasi Responden Terhadap Indikator Kompentensi Supervisi Akademik

\begin{tabular}{|c|c|c|}
\hline No. & Uraian & Implementasi \\
\hline 1 & $\begin{array}{l}\text { Memahami perkembangan mata } \\
\text { palajaran yang ditugaskan }\end{array}$ & $100.00 \%$ \\
\hline 2 & $\begin{array}{l}\text { Memahami perkembangan proses } \\
\text { pembelajaran mata pelajaran yang } \\
\text { ditugaskan }\end{array}$ & $100.00 \%$ \\
\hline 3 & $\begin{array}{l}\text { Membimbing guru menyusun silabus } \\
\text { berdasarkan SI, SK, SD dan prinsip } \\
\text { pengb. KTSP }\end{array}$ & $96.00 \%$ \\
\hline 4 & $\begin{array}{l}\text { Membimbing guru memilih dan } \\
\text { menggunakan strategi/metode/teknik } \\
\text { pembelajaran. }\end{array}$ & $96.00 \%$ \\
\hline 5 & Membimbing guru menyusun RPP & $100.00 \%$ \\
\hline 6 & $\begin{array}{l}\text { Membimbing guru melaksanakan } \\
\text { kegiatan pembelajaran }\end{array}$ & $100.00 \%$ \\
\hline \multirow[t]{4}{*}{7} & \multicolumn{2}{|c|}{ Media Pendidikan dan Fasilitas Pembelajaran } \\
\hline & $\begin{array}{l}\text { 7.1 Membimbing guru menggunakan } \\
\text { media dan fasilitas pembelajaran }\end{array}$ & $100.00 \%$ \\
\hline & $\begin{array}{l}\text { 7.2 Membimbing guru mengelola dan } \\
\text { mengemb. media dan fasilitas } \\
\text { pembelajaran }\end{array}$ & $96.00 \%$ \\
\hline & $\begin{array}{l}\text { 7.3 Membimbing guru merawat } \\
\text { media dan fasilitas pembelajaran }\end{array}$ & $92.00 \%$ \\
\hline 8 & $\begin{array}{l}\text { Memotivasi guru memanfaatkan } \\
\text { teknologi informasi dalam } \\
\text { pembelajaran }\end{array}$ & $100.00 \%$ \\
\hline
\end{tabular}

Terdapat indikator kompetensi evaluasi pendidikan yang telah diimplementasikan secara tepat oleh sejumlah $100 \%$ responden, dan terdapat pula indikator yang hanya diimplementasikan oleh hanya sejumlah $88 \%$ responden. Indikator yang telah diimplementasikan oleh sejumlah $100 \%$ responden adalah : (a) membantu kepala madrasah menyusun kriteria dan indikator keberhasilan pembelajaran; (b) membimbing guru menentukan aspekaspek yang penting dinilai dalam pembelajarn; (c) Memantau pelaksanaan pembelajaran yang dilakukan guru Mata pelajarandan (d) melakukan analisis hasil belajar siswa. Indikator yang telah diimplementesikan oleh sejumlah 90-99\% responden adalah (a) menilai kinerja kepala dan 
(b) guru madrasah melakasanakan tugas pokok dan tanggung jawab; dan (c) memantau hasil belajar siswa. (d) mengelola dan menganalisis data hasil penilaian kinerja kepala madrasah, guru dan staf. Indikator yang telah diimplementasikan oleh sejumlah $88 \%$ responden adalah menilai kinerja staf administrasi melaksanakan tugas pokok dan tanggung jawab.Lebih jelasnya dapat diamati tabel berikut:

Tabel 6 Implementasi Responden Terhadap Indikator Kompetensi Evaluasi Pendidikan

\begin{tabular}{clc}
\hline No. & \multicolumn{1}{c}{ Uraian } & Implementasi \\
\hline 1 & $\begin{array}{l}\text { Membantu Kamad menyusun } \\
\text { kriteria dan indikator keberhasilan } \\
\text { pembelajaran }\end{array}$ & $100.00 \%$ \\
\hline & Meman
\end{tabular}

2 Membimbing guru menentukan aspek-aspek yang penting dinilai dalam pembelajaran

3 Penilaian Kinerja

3.1. Menilai kinerja Kamad melaksanakan tugas pokok dan tanggung jawab.

3.2 Menilai kinerja guru melaksanakan tugas pokok dan tanggung jawab.

3.32. Menilai kinerja staf administrasi melaksanakan tugas pokok dan tanggung jawab.

Pelaksanaan Pembelajaran

4.1. Memantau pelaksanaan pembelajaran yang dilakukan guru Mapel

4.2 Memantau hasil belajar siswa

4.3. Melakukan analisis hasil belajar siswa

5 Mengelola dan menganalisis data hasil penilaian kinerja Kamad, guru dan staf

Pada kompetensi penelitian dan pengembangan, tampak bahwa dominan indikator telah diimplementesikan oleh sejumlah di bawah $55 \%$ responden, kecuali pada indikator kompetensi mengindentifikasi masalah kepengawasan. Dua indikator berikutnya diimplementasikan oleh sejumlah 54\% dan 52\% responden yaitu: menyusun proposal penelitian dan melaksanakan penelitian. Indiaktor yang lain diimplementasikan oleh sejumlah dibawah $50 \%$ responden. Lebih jelasnya dapat diamati tabel 7 .
Tabel 7 Tingkat Implementasi Responden Terhadap Indikator Kompentensi Penelitian dan Pengembangan

\begin{tabular}{clc}
\hline No. & \multicolumn{1}{c}{ Uraian } & Implementasi \\
\hline 1 & $\begin{array}{l}\text { Mengidentifikasi masalah } \\
\text { kepengawasan }\end{array}$ & $84.00 \%$ \\
2 & Menyusun proposal penelitian & $54.00 \%$ \\
3 & Melaksanakan penelitian & $52.00 \%$ \\
4 & Mengolah dan menganalisis data & $32.00 \%$ \\
5 & Menulis karya tulis ilmiah & $24.00 \%$ \\
6 & $\begin{array}{l}\text { Menyusun panduan atau modul } \\
\text { kepengawasan }\end{array}$ & $20.00 \%$ \\
7 & $\begin{array}{l}\text { Membimbing guru melakukan } \\
\text { penelitian tindakan kelas }\end{array}$ & $40.00 \%$ \\
8 & $\begin{array}{l}\text { Pengembangan Profesi } \\
\text { 8.1 Penelitian }\end{array}$ & \\
& 8.2 Menemukan teknologi tepat & guna \\
& 8.3 Membuat alah peraga/bimbingan & $24.00 \%$ \\
& 8.4. Menciptakan karya seni & $12.00 \%$ \\
8.5 Mengikuti kegiatan & pengembangan kurikulum & $16.00 \%$ \\
\hline
\end{tabular}

Pada kompetensi sosial, tampak bahwa indikator kompetensi telah diimplementasikan oleh sejumlah $84 \%$ sampai $100 \%$ responden.Dominan indikator telah diimplementasikan oleh sejumlah $100 \%$ responden kecuali pada tiga indikator. Ketiga indikator itu adalah (a) membangun kemitraan dangan Kementerian Agama/Diknas dalam rangka meningkatkan kualitas diri dan melaksanakan tugas kepengawasan (88\% responden), (b) membangun kemitraan dengan majelis kerja sekolah/madrasah dalam rangka melaksanakan tugas kepegawaian (96\% responden), dan(c) aktif dalam kegiatan asosiasi pengawas ( $84 \%$ responden).

Tabel 8 Tingkat Implementasi Responden

TerhadapIndikator Kompentensi Sosial

\begin{tabular}{|c|c|c|}
\hline No. & Uraian & Implementasi \\
\hline \multirow[t]{7}{*}{1} & \multicolumn{2}{|c|}{$\begin{array}{l}\text { Membangun kemitraan dalam rangka meningkatkan } \\
\text { kualitas diri }\end{array}$} \\
\hline & 1.1 Kemenag/Kemediknas & $88 \%$ \\
\hline & 1.2 Sesama pengawas & $100 \%$ \\
\hline & 1.3 Majelis Kerja Sekolah/Madrasah & $100 \%$ \\
\hline & 1.4 Majelis Guru Mata Pelajaran & $100 \%$ \\
\hline & 1.5 Kepala Madrasah & $100 \%$ \\
\hline & 1.6. Guru Mata Pelajaran & $100 \%$ \\
\hline
\end{tabular}


2 Membangun kemitraan dalam rangka melaksanakan tugas kepengawasan

2.1 Kemenag/Kemediknas

$100 \%$

2.2 Sesama pengawas

$100 \%$

2.3 Majelis Kerja Sekolah/Madrasah

$96 \%$

2.4 Majelis Guru Mata Pelajaran

$100 \%$

2.5 Kepala Madrasah

$100 \%$

2.6. Guru Mata Pelajaran

$100 \%$

3 Aktif dalam kegiatan asosiasi pengawas

Berdasarkan implementasi terhadap indikator setiap kompetensitersebut, maka tingkatkompetensi responden (pengawas) di Kota Kendari terkategori sedang. Diamati setiap komponen kompetensi, ada sejumlah limakomponen kompetensi terkategori tinggi yaitu kompetensi Keperibadian, Supervisi Manajemen, Supervisi Akademik, Evaluasi Pendidikan, dan Sosial. Satu komponen yang terkategori rendah yaitu komponen kompetensi penelitian dan pengembangan.Lebih jelasnya dapat diamati tabel 9.

Tabel 9 Tingkat Kompetensi Responden Berdasarkan Komponen Kompetensi

\begin{tabular}{clcc}
\hline No & \multicolumn{1}{c}{ Kompetensi } & Tingkat & Kategori \\
\hline 1 & Keperibadian & 3.37 & Tinggi \\
2 & Supervisi Manajemen & 3.14 & Tinggi \\
3 & Supervisi Akademik & 3.2 & Tinggi \\
4 & Evaluasi Pendidikan & 3.02 & Tinggi \\
5 & Penelitian dan & 1.05 & Rendah \\
& Pengembangan & & \\
6 & Sosial & 3.43 & Tinggi \\
Total & & 2.87 & Sedang \\
\hline
\end{tabular}

\section{Tingkat Kompetensi Pengawas}

\section{Tingkat Kompetensi Berdasarkan Usia Saat Diangkat Pengawas}

Masih terdapat pengawas madrasah yang diangkat dalam usia di atas 45 tahun, bahkan pada usia menjelang pensiun yaitu 55 tahun. Kebijakan ini dianggap mempengaruhi tingkat kompetensi pengawas, sebagai tenaga supervisi dan pemantau tingkat kualitas guru di madrasah. Karenanya dalam upaya membuktikan anggapan tersebut, maka analisis tingkat kompetensi pengawas berdasarkan usia saat diangkat dilakukan.

Dalam konteks penelitian ini, tampak terdapat asosiasi antara tingkat kompetensi pengawas dengan usianya saat diangkat. Semakin tinggi tingkat usia responden diangkat sebagai pengawas maka tingkat kompetensinya tampak merendah. Responden yang diangkat pada usia 32-43 tahun memperlihatkan tingkat kompetensi yang tinggi. Namun pengawas yang diangkat pada usia 44-60 tahun tampak memiliki kompetensi sedang.

Tabel 10 Tingkat Kompetensi Pengawas Berdasarkan Usia Saat Diangkat

\begin{tabular}{ccc}
\hline Usia Saat Diangkat & Tingkat & Kategori \\
\hline $32-37 \mathrm{TH}$ & 3.1 & Tinggi \\
$38-43 \mathrm{TH}$ & 3.3 & Tinggi \\
$44-49 \mathrm{TH}$ & 3 & Sedang \\
$50-55 \mathrm{TH}$ & 2.7 & Sedang \\
$56-62 \mathrm{TH}$ & 2.9 & Sedang \\
\hline
\end{tabular}

Diamati berdasarkan aspek kompetensi, kecendrungan tersebut diatas tampak pada aspekaspek yang berkaitan langsung dengan tugas-tugas kepengawas pendidikan (tugas pokok pengawas), yaitu supervisi manajerial, supervisi akademik, dan evaluasi pendidikan. Pada aspek kompetensi manajerial, meskipun pengawas yang diangkat pada usia 32-55 tahun terkategori tinggi. Namun kecenderungan penurunan tingkat kompetensi itu telah tampak pada usia 44 tahun ke atas (skor tingkat kompetensinya adalah 3.21, menurun dari kelompok usia sebelumnya:3.5) pada aspek kompetensiakademik, tingkat kompetensi pengawas tampak terkategori rendah pada kelompok usai 5055 tahun dan 56-60 tahun. Demikian halnya dengan aspek kompetensi evaluasi pendidikan.

Berbeda dengan kompetensi kelitbangan, keperibadian dan sosial.Tampak bahwa kompetensi kelitbangan pengawas madrasah rendah ke sedang. Terdapat empat kelompok usia responden yang terkategori rendah, dan hanya kelompok usia 38-43 tahun yang memiliki tingkat kompetensi kelitbangan terekategori sedang. Sementara tingkat kompetensi keperibadian dan sosial responden terkategori tinggi di semua kelompok usia. 
Tabel 11 Tingkat Kompetensi Pengawas Berdasarkan Usia Saat Diangkat Dilihat Menurut Aspek Kompetensi

\begin{tabular}{ccccccccccccc}
\hline $\begin{array}{c}\text { Usia Saat } \\
\text { Diangkat }\end{array}$ & \multicolumn{2}{c}{$\begin{array}{c}\text { Supevisi } \\
\text { Manajerial }\end{array}$} & \multicolumn{2}{c}{$\begin{array}{c}\text { Supevisi } \\
\text { Akademik }\end{array}$} & \multicolumn{2}{c}{$\begin{array}{c}\text { Evaluasi } \\
\text { Pendidikan }\end{array}$} & Kelitbangan & Keperibadian & Sosial \\
\hline 32-37 TH & 3.5 & Tinggi & 3.5 & Tinggi & 3.5 & Tinggi & 1 & $\begin{array}{c}\text { Sangat } \\
\text { Rendah }\end{array}$ & 3.5 & Tinggi & 3.5 & Tinggi \\
& & & & & & & & & & & \\
38-43 TH & 3.5 & Tinggi & 3.5 & Tinggi & 3.5 & Tinggi & 2.33 & Sedang & 3.5 & Tinggi & 3.17 & Tinggi \\
44-49 TH & 3.21 & Tinggi & 3.36 & Tinggi & 3.07 & Tinggi & 1.57 & Rendah & 3.21 & Tinggi & 3.36 & Tinggi \\
$50-55$ TH & 3.14 & Tinggi & 2.77 & Sedang & 2.77 & Sedang & 1.27 & Rendah & 3.14 & Tinggi & 3.23 & Tinggi \\
56-62 TH & 2.83 & Sedang & 2.83 & Sedang & 2.83 & Sedang & 2 & Rendah & 3.17 & Tinggi & 3.5 & Tinggi \\
\hline
\end{tabular}

Tingkat Kompetensi Pengawas Berdasarkan Disiplin Ilmu

Selain pengawas diangkat pada usia menjelang pensiun, terdapat pula pengawas yang diangkat yang sebelumnya menjabat jabatan non kependidikan. Berdasarkan Peraturan Menteri Pendidikan Nasional RI Nomor 12 Tahun 2007 tentang Standar Pengawas Sekolah/Madrasah, pasal 31 ayat 1.a bahwa PNS yang diangkat dalam jabatan pengawas sekolah/madrasah berstatus sebagai guru dan memiliki sertifikat pendidik dengan berpengalaman mengajar paling sedikit 8 (delapan) tahun atau guru yang diberi tugas tambahan sebagai kepala sekolah/madrasah paling sedikit 4 (empat) tahun sesuai dengan satuan pendidikannya masingmasing.

Dalam konteks penelitan ini, dominan responden menjabat sebagai guru dan kepala madrasah sebelumnya dan berkompetensi sedang. Tampak bahwa tingkat komptensi pengawas yang menduduki jabatan kepala madrasah lebih tinggi dari pada pengawas yang menduduki jabatan guru mata pelajaran sebelumnya.

Hal yang menarik pada penelitian ini, tingkat kompetensi pengawas yang menduduki jabatan selain kepala madrasah dan guru lebih tinggi. Pejabat yang membidangi kependidikan pada instansi struktural (Kantor Kementerian Agama baik Provinsi maupun Kabupaten/Kota) memiliki tingkat kompetensi yang sama dengan pengawas yang menduduki jabatan kepala madrasah sebelumnya. Sementara pengawas yang menduduki jabatan non kependidikan berkompentensi tinggi.
Tabel 12 Tingkat Kompetensi Pengawas Berdasarkan Jabatan Sebelumnya

\begin{tabular}{lll}
\hline Jabatan Sebelumnya & Tingkat & Kategori \\
\hline Non Bidang Kependidikan & 3 & Sedang \\
Bidang Kependidikan & 2.9 & Sedang \\
Kepala Madrasah & 2.9 & Sedang \\
Guru Mata Pelajaran & 2.8 & Sedang \\
\hline
\end{tabular}

Namun setelah diamati berdasarkan aspek kompetensi, lima tingkat komptensi guru dan madrasah terkategori tinggi, yaitu kompetensi supervisi manajerial, supervisi akademik, evaluasi pendidikan, keperibadian dan sosial, namun tingkat kompetensi kelitbangannya terkategori rendah. Sedangkan pengawas yang menjabat bidang kependidikan di Kantor Kementerian Agama berkompetensi tinggi pada aspek supervisi manajerial, evaluasi pendidikan, dan sosial; berkomptensi sedang pada aspek supervisi akademik dan keperibadian; dan berkompetensi rendah pada aspek kelitbangan. Sementara pengawas yang menduduki jabatan non kependidikan sebelumnya berkompetensi tinggi pada aspek supervisi manajerial, keperibadian, dan sosial; dan berkompetensi rendah pada aspek kelitbangan. Sementara pengawas yang menduduki jabatan non kependidikan sebelumnya berkompetensi tinggi pada aspek supervisi manajerial, keperibadian, dan sosial; berkompetensi sedang aspek supervisi akademik, evaluasi pendidikan, dan kelitbangan.

Tampaknya pengangkatan pengawas yang menduduki jabatan selain guru dan kepala madrasah lebih disebabkan oleh pertimbangan kompetensi manajerial, kelitbangan, keperibadian, dan sosial. 
Tabel 13 Tingkat Kompetensi Pengawas Berdasarkan Jabatan SebelumnyaDilihat Menurut Aspek Kompetensi

\begin{tabular}{cccccccccccccc}
\hline $\begin{array}{c}\text { Jabatan } \\
\text { Sebelumnya }\end{array}$ & \multicolumn{2}{c}{$\begin{array}{c}\text { Supevisi } \\
\text { Manajerial }\end{array}$} & \multicolumn{2}{c}{$\begin{array}{c}\text { Supevisi } \\
\text { Akademik }\end{array}$} & \multicolumn{2}{c}{$\begin{array}{c}\text { Evaluasi } \\
\text { Pendidikan }\end{array}$} & Kelitbangan & \multicolumn{2}{c}{ Keperibadian } & Sosial \\
\hline Non Bid. Pend & 3.5 & Tinggi & 2.7 & Sedang & 2.9 & Sedang & 2.2 & Sedang & 3.1 & Tinggi & 3.5 & Tinggi \\
Bid. Pend. & 3.5 & Tinggi & 3 & Sedang & 3.1 & Tinggi & 1.5 & Rendah & 3 & Sedang & 3.5 & Tinggi \\
Kamad & 3.38 & Tinggi & 3.07 & Tinggi & 3.3 & Tinggi & 1.25 & Rendah & 3.3 & Tinggi & 3.24 & Tinggi \\
Guru MP & 3.06 & Tinggi & 3.06 & Tinggi & 3.17 & Tinggi & 1.44 & Rendah & 3.17 & Tinggi & 3.17 & Tinggi \\
\hline
\end{tabular}

Tingkat Kompetensi Pengawas Berdasarkan Disiplin Ilmu

Pengangkatan pengawas madrasah juga terkadang tidak sesuai dengan latar belakang disiplin ilmunya.Beberapa kasus terjadi pengawas diangkat untuk mengawasi bidang studi yang tidak sesuai dengan disiplin ilmunya.Dalam kontek penelitian ini dominan pengaawas di Kota Kendari telah diangkat di tugaskan untuk mengawasi guruguru bidang studi sesuai dengan disiplin ilmunya, kecuali hanya seorang pengawas.

Tampak bahwa tidak ada perbedaan kompetensi antara pengawas yang berlatar belakang disiplin ilmu agama dan umum.Keduakelompok pengawas ini terkatogori berkompetensi sedang. Sementara pengawas yang diangkat tidak sesuai dengan disiplin ilmunya memiliki kompetensi yang tinggi.

Tabel 14 Tingkat Kompetensi Pengawas Berdasarkan Disiplin Ilmu

\begin{tabular}{lcc}
\hline \multicolumn{1}{c}{ Disiplin Ilmu } & Tingkat & Kategori \\
\hline Agama tdk sesuai & 3.1 & Tinggi \\
Umum Sesuai & 2.8 & Sedang \\
Agama sesuai & 2.9 & Sedang \\
\hline
\end{tabular}

Diamatiberdasarkanaspekkompotensitampak terdapat keseragaman tingkat komptensi pengawas pada aspek supervisi manajerial, kelitbangan, dan sosial.Tingkat kompetensi supervisi manajerial dan sosial ketiga kelompok pengawas tersebut terkategori tinggi, sementara pada aspek kelitbangan berkompetensi rendah.Namun pada aspek kompetensi supervisi akademik, evaluasi pendidikan, dan keperibadian tempak berpola tertentu.Pengawas berdisiplin ilmu pengetahuan umum yang ditugasi mengawasi bidang studi sesuai dengan disiplin ilmunya berkopentensi sedang pada aspek supervisi akademik, evaluasi pendidikan, dan keperibadian. Sementara pengawasagama yang ditugasi mengawasi bidan studi yang sesuai dan tidak sesuai dengan disiplin ilmunya berkompentensi tinggi.

Kondisi ini dapat diinterpretasi bahwa, dalam konteks penelitian ini, kebijakan pengangkatan pengawas madarash yang tidak sesuai dengan disiplin ilmunya dilakukan dengan pertimbangan kompetensi supervisi manajerial, supervisi akademik, evaluasi pendidikan, keperibadian dan sosial.

Tabel 15 Tingkat Kompetensi Pengawas Berdasarkan Disiplin Ilmu Dilihat Menurut Aspek Kompetensi

\begin{tabular}{|c|c|c|c|c|c|c|c|c|c|c|c|c|}
\hline \multirow{2}{*}{$\begin{array}{c}\text { Kesesuaian Disiplin Ilmu } \\
\text { Agama tdk sesuai }\end{array}$} & \multicolumn{2}{|c|}{$\begin{array}{c}\text { Supevisi } \\
\text { Manajerial }\end{array}$} & \multicolumn{2}{|c|}{$\begin{array}{c}\text { Supevisi } \\
\text { Akademik }\end{array}$} & \multicolumn{2}{|c|}{$\begin{array}{c}\text { Evaluasi } \\
\text { Pendidikan }\end{array}$} & \multicolumn{2}{|c|}{ Kelitbangan } & \multicolumn{2}{|c|}{ Keperibadian } & \multicolumn{2}{|c|}{ Sosial } \\
\hline & 3.5 & Tinggi & 3.17 & Tinggi & 3.17 & Tinggi & 2 & & 5.0 & & 3.5 & \\
\hline Umum Sesuai & 3.5 & Tinggi & 3 & Sedang & 2.5 & Sedang & 1.5 & & 3 & & 3.5 & Tinggi \\
\hline Agama sesuai & 3.1 & Tinggi & 3.05 & Tinggi & 3 & Tinggi & 1.5 & Rendah & 3.2 & Tinggi & 3.25 & Tinggi \\
\hline
\end{tabular}

\section{PENUTUP}

Secara umum Tingkat kompetensi pengawas madrasah di Kota Kendari terkategori sedang.Lima komponen kompetensi pengawas terkategori tinggi dan satu komponen terkategori rendah.Komponen kompetensi pengawas madrasah yang terkategori tinggi adalah komponen kompotensi keperibadian, supervisi manajerial, supervisi akademik, evaluasi pendidikan dan sosial.Sedangkan kompetensi pengawas yang terkategori rendah adalah kompetensi penelitian dan pengembangan.

Tingkat kompetensi pengawas berdasarkan karakteristik pengawas tampak variatif.Meskipun demikian tingkat kompetensi tersebut umumnya 
terkategori rendah ke tinggi.Pengawas yang berkompetensi tertinggi adalah pengawas yang angkat pada berusia 44-49 tahun, menjabat sebagai guru mata pelajaran sebelum diangkat menjadi pengawas, dan disiplin ilmu sesuai dengan mata pelajaran yang diawasi.

\section{UCAPAN TERIMA KASIH}

Penelitian ini telah selesai setelah melalui sejumlah tahapan, mulai dari perancangan, diskusi dengan beberapa nara sumber ahli, pengumpulan data, analisis, penyusunan makalah/laporan, seminar sampai pada publikasi melalui Jurnal Penelitian Agama dan Sistem Al-Qalam. Disadari, bahwa sungguh banyak person yang terlibat dalam setiap proses penelitian tersebut, karenanya peneliti mengucapkan terima kasih kepada Prof. Dr. Muhammad Ardi, M.Pd. selaku konsultan penelitian, Kepala Kanwil Provinsi Sulawesi Utara dan Kendep Kementerian Agama Kota Kendari beserta seluruh staf dan pengawas PAI, Kepala Balai Penelitian dan Pengembangan Agama selaku pimpinan peneliti, dan terakhir Pelindung, Penanggung Jawab dan Dewan Redaksi Al-Qalam yang telah menyeleksi dan menerbitkan tulisan ini.

\section{DAFTAR PUSTAKA}

Arikunto, Suharsimin. 2005. Manajemen Penelitian. Jakarta: Rineka Cipta.

Balai Litbang Agama Makassar. 2004. Laporan Penelitian Performansi Pengawas dan Guru PAI di Sekolah Umum di Sulawesi Tenggara.

Biro Hukum dan Organisasi Departemen Pendidikan Nasional, Salinan Lampiran Peraturan Menteri Pendidikan Nasional Nomor 12 Tahun 2007 Tanggal 28 Maret 2007 Standar Pengawas Sekolah/Madrasah.

Direktorat Jenderal Peningkatan Mutu Pendidik Dan Tenaga Kependidikan Departemen Pendidikan Nasional, 2009, Bahan Belajar Mandiri Kelompok Kerja Pengawas Sekolah Dimensi Kompetensi Keperibadian dan Dimensi Kompetensi Sosial Bagian II Jakarta : Direktorat Jenderal Peningkatan Mutu Pendidik Dan Tenaga Kependidikan Departemen Pendidikan Nasional. --. 2009, Bahan Belajar Mandiri Kelompok Kerja Pengawas Sekolah Dimensi Kompetensi Supevisi Akademik Jakarta : Direktorat Jenderal Peningkatan Mutu Pendidik
Dan Tenaga Kependidikan Departemen Pendidikan Nasional.

--. 2009, Bahan Belajar Mandiri Kelompok Kerja Pengawas Sekolah Dimensi Kompetensi Penelitian dan Pengembangan Jakarta : Direktorat Jenderal Peningkatan Mutu Pendidik Dan Tenaga Kependidikan Departemen Pendidikan Nasional.

-------. 2009, Bahan Belajar Mandiri Kelompok

Kerja Pengawas Sekolah Dimensi Evaluasi Pendidikan Jakarta : Direktorat Jenderal Peningkatan Mutu Pendidik Dan Tenaga Kependidikan Departemen Pendidikan Nasional.

-------. 2009. Bahan Belajar Mandiri Kelompok Kerja Pengawas Sekolah Dimensi Kompetensi Supervisi Manajerial Jakarta : Direktorat Jenderal Peningkatan Mutu Pendidik Dan Tenaga Kependidikan Departemen Pendidikan Nasional.

Gulo, W. 2010. Metodologi Penelitian. Jakarta: Grasindo.

Keputusan Menteri Pendayag unaan Aparatur Negara No. 118/1996 yang dirubah dengan Keputusan Menpan No. 91/2001 tentang Jabatan Fungsional Pengawas Sekolah dan Angka Kreditnya.

Mulyatningsih, Endang. 2013. Metode Penelitian Terapan Bidang Pendidika. Bandung: Alfabeta.

Mustari, Kahar. 2012. Analisis Statistika dengan SPSS. Makassar: Masagena Press.

Nasution, Suhri. 2010. "Profesionalisme Pengawas PAI Dibidang Supervisi Akademik”. bdkjakarta.kemenag.go.id. 12/2/ 2012.

Peraturan Menteri Pendidikan Nasional No. 12 Tahun 2007 tentang Standar Pengawas Sekolah/ Madrasah.

Peraturan Pemerintah Republik Indonesia No. 19 Tahun 2005 tentang Standar Nasional Kependidikan.

Raco, J.R. 2010. Metode Penelitian Kualitatif, Jenis, Karakteristik, dan Keunggulannya. Jakarta: Gramedia.

Seleuw, Marwan. 2009. "Pelaksanaan Supervisi Pengawas Penidikan Agamaa Islam pada Kegiatan Belajar Mengajar di Madrasah Ibtidaiyah Jayapura”. lib.uin-malang. ac.id. 12/2/2012. 